Covered in: ERIH PLUS, CEEOL, Index Copernicus, CrossRef, CrossCheck, J-Gate, Google Scholar, Ideas RePeC, Econpapers, Socionet, KVK, WorldCat.

2018, Volume 7, Issue 1, pages: 100-104 | doi: https://doi.org/10.18662/lumenss/11

\section{Review of the} Volume "Principii și metode de rezolvare diplomatică a diferendelor internaționale" [Principles and Methods of Diplomatic Settlement of International Disputes], Author Dan Alexandru Gună, Published by Lumen Publishing House

\section{Alexandra HUIDU1}

${ }^{1} \mathrm{PhD}$ Student, Doctoral School of Sociology of the University of Oradea, Oradea, Romania;

LUMEN Research Center in Social and Humanistic Sciences, andra huidu@yahoo.com

\begin{abstract}
The book "Principles and Methods of Diplomatic Settlement of International Disputes" is a work from a difficult field of law. Diplomatic and consular law has always hampered the interest of lawyers because it has always been a topicality field. Therefore, any collection of legal books would be incomplete without works in this area of law, alongside classical law domains. From this point of view, this book is a valuable acquisition for any legal collection that is intended to be complete.
\end{abstract}

Keywords: diplomatic princples; diplomatic methods; diplomatic settlement of disputes; international differences; Dan Alexandru Gună; book review.

How to cite: Sandu, A. (2018). Review of the Volume "Principii și metode de rezolvare diplomatică a diferendelor internaţionale" [Principles and Methods of Diplomatic Settlement of International Disputes], Author Dan Alexandru Gună, Published by Lumen Publishing House. Logos Universality Mentality Education Novelty: Social Sciences, 7(2), 100104. https://doi.org/10.18662/lumenss/11 



\section{Introduction}

Dan Alexandru Gună is a lecturer $\mathrm{PhD}$ at the Faculty of Law and Administrative Sciences of Valahia University in Târşovişte, Romania. Graduate of the Master program in European Public Administration and wiith a Law PhD from the Romanian Academy - "Academician Andrei Rădulescu" Legal Research Institute, the author has been interested in several fields of law, including public international law, civil law and environmental law, disciplines he has also taught as a professor in the university.

The book "Principles and Methods of Diplomatic Settlement of International Disputes" is an extensive and complex work related to the broader field of diplomatic and consular law, as a branch of law derived from public international law. In this volume, the scientific analysis is well structured, well documented and deals with topical issues, which recommends that this monograph is valuable from all points of view. However, taking into consideration the area of the law which the book approaches, we can not fail to notice that the area of readers to whom it is addressed is a niche, but not for reasons of quality of work, but only for this strictly motivated reason. Beyond this particular element, which is not a fault of the author, however, the book is topical in the context of a world in constant conflict, in which violent manifestations are widening under the pressure of terrorism and arms trafficking, and conflicts tend to swiftly overcome, due to the phenomenon of globalization, national borders. Also, the actuality of the paper is noted in the context of redefining Romania's position as a real player in international diplomacy in Europe, but also in its capacity as a NATO member, meaning that Romania can play the role of a balanced actor or mediator. In all other aspects, the book has scientific value for research in the field, it is well documented bibliographically, the topics proposed by the author for analysis are treated properly, clearly and organized in a stylish discourse.

\section{The talent for diplomacy and the talent for explaining diplomacy}

The author realizes what he has intended with this volume, according to his own statements in the "introduction" section, namely to capture the approach of states in the peaceful settlement of international disputes and to analyze the proper methods for achieving this. The author does not go directly to presenting methods of diplomatic dispute resolution, but initially analyzes general principles in the field, and places these methods 
in a wider context, a practical one, when addressing issues related to new contemporary challenges of solving international disputes. Only then begins the analytical discourse of the book itself.

The methods of peaceful settlement of international disputes are presented not only theoretically, but also with relevant examples of international diplomacy, important and interesting statistical data, which are then interpreted by the author to make a comparative analysis of these methods and highlight the advantages and disadvantages of each of them, depending on the type of dispute to which it will be applied. We do not see how an analysis of the research topic could be approached in a better or more complete way, so we appreciate that there are no topics or information about the research theme missing from the volume.

What makes the reading of this book pleasant, beyond the strict scientific interest, is that the author avoids common phrases or ideas and is courageous in approaches and conclusions, and the themes he chooses to emphasize are precisely those that appeal to the reader's interest. The author has a special sense in giving the reader exactly the novelty elements that he would look for in such a work. At the same time, the space allocated to the themes proposed for analysis is divided by the author, as he himself shows in the paper, depending on the efficiency of a negotiation method or the other, based on statistical data.

Where these data show that the method is preferred by states and provides results, the method is given due attention. The other methods, less optimal in international diplomatic practice or with inconstant effects in diplomacy, are dealt with briefly, but not superficially, and the author focuses his attention on identifying the reasons why these methods are not popular. Thus, the author manages to make a well-proportioned analysis of the subject in question, without losing sight of certain topics of interest and giving them the importance they deserve, on practical grounds.

\section{Structure and rigor}

The book is voluminous and abounds in information, analysis, synthesis, viewpoints, so it can not be argued that any topic approached in the monograph would be incompletely treated. As for the topics of discussion that the author emphasizes, they are not arbitrarily chosen, but based on statistical and practical considerations, as shown above.

The strengths of the work are particularly noteworthy in the field of practical examples and case studies presented in the paper. These are not only listed or indicated as a reference, but are widely analyzed and used as 
the basis for pertinent, well-grounded conclusions. Then the author uses statistical data to support his assertions, a method of approach that is rarely found in legal research and which adds value to the present work while helping the reader to capture the importance of ideas presented in the volume and why some aspects are particularly emphasized. What is even more remarkable is the author's preoccupation with choosing examples that bring into attention the diplomatic practice of Romania, when such examples can be found.

Without any doubt, the monograph is dedicated to law specialists, but not only. It can be a source of information and explanation for all those interested in or working in areas related to diplomacy. However, law specialists are primarily concerned with topics in this volume, so the target audience is the one specific to a law book.

The structure of the manuscript is a classic one, based on the general principles applicable in the matter (chapter I). What goes beyond the classic framework of organizing a book about research in the field of law is the insertion of Chapter II - Section 2.1., which is essentially a plea for the importance of diplomatic methods for solving international disputes in the conditions of transforming the contemporary world, an aspect that attracts the attention of the reader that the actual analysis of the theme, which is done further in chapter II and chapter III, starts from a series of particular circumstances. We consider the author's choice to insert section 2.1. in Chapter II was a good decision and brings a lot of authenticity and topicality to the work.

Then, the author returns to the classical structure of such a monograph, approaching each diplomatic method of peaceful solution of international conflicts and analyzing it distinctly according to its peculiarities. Although during the second chapter the author makes reference, in each analyzed method, to the role of mediators, of third parties in solving disputes, in a separate chapter (Chapter III), he analyzes the role of third party involvement in disputes and he highlights the qualities desirable for third party mediator in order to have a successful intervention, focusing not on the benefits of a method or other forms of negotiation, but rather on the role of the negotiator. The fact that the author brings the human factor to the foreground in this way is another element of structuring the scientific discourse that adds to the originality of the work.

The references list is extensive and the authors cited are well-chosen, especially as information sources are extremely numerous in this area, and the author knew how to discern and choose the relevant ones. At the basis 
of this references list are numerous international treaties and conventions. So, we appreciate the rigorous documentation of the work.

\section{Conclusions}

This book is of high actuality, interest and scientific importance, and it is in line with contemporary diplomatic activities. as it presents the reader with an optimal configuration of the discourse. It is a complex, extensive and well documented analysis. Although addressed to law researchers and practitioners, it can also be of interest to historians, political analysts, diplomats etc., and the author comes to their aid by the way he introduces and explains legal concepts, so as to keep the readers interested and motivate them in pursuing the scientific discourse.

This monograph is an elegant paper. The book is written from the point of view of the scientist, but it is evident throughout the book that the author is also a good writer, because he addresses the issues in a language accessible to the general public without, however, abandoning the rigors of scientific language. We would like to emphasize that the scientific and, at the same time, political controversy, the diversity and the extent of the controversies generated by the topics analyzed in the book, is supported by the examples presented. All this transforms the work into an interesting book that invites to the act of reading without disappointing, but confirming the reader's motivation until the end.

\section{Acknowledgement}

This paper was elaborated within the doctoral research entitled "Social and Bioethical Acceptance of Techniques Related to Medically Assisted Human Reproduction in Romania", within and with funding by the doctoral scholarship awarded by the Doctoral School of Sociology, University of Oradea, Romania. The research is carried out in cocoordination with the University of Medicine and Pharmacy Grigore T. Popa from Iasi, Romania.

\section{References}

Gună, D. A. (2015). Principii şsi metode de rezolvare diplomatică a diferendelor internationale [Principles and methods of diplomatic resolution of international differences]. Iaşi, Romania: Lumen. 